\title{
Short-term Outcomes in Children Recovered from Multisystem Inflammatory Syndrome associated with SARS-CoV-2 infection
}

Authors: $\quad$ Sibabratta Patnaik, Mukesh Kumar Jain, Sakir Ahmed, Arun Kumar Dash,

Ram Kumar P, Bandya Sahoo, Reshmi Mishra, Manas Ranjan Behera

\section{Dr Sibabratta Patnaik}

MD, IDPCCM

Associate Professor, Pediatrics

Kalinga Institute of Medical Sciences, Bhubaneswar, India

ORCID: 0000-0002-3020-4229

drsbpatnaik45@gmail.com

2. Dr Mukesh Kumar Jain

Assistant professor, Pediatrics

Kalinga Institute of Medical Sciences, Bhubaneswar, India ORCID 0000-0002-6216-2131

\section{Dr Sakir Ahmed}

Associate Professor

Dept of Clinical Immunology and Rheumatology

Kalinga Institute of Medical Sciences, Bhubaneswar, India

Orcid: 0000-0003-4631-311X

sakir005@gmail.com

\section{Dr Arun Kumar Dash}

Senior Resident, Dept of Pediatrics

Kalinga Institute of Medical Sciences, Bhubaneswar

ORCID: 0000-0002-0682-4225

\section{Dr Ram Kumar $\mathbf{P}$}

Junior Resident, Dept of Pediatrics

Kalinga Institute of Medical Sciences, Bhubaneswar, India ramu@gmail.com

\section{Dr Bandya Sahoo}

MD, Felowship in Pediatric Intensive care (IAP)

Professor, Dept of Pediatrics,

Kalinga Institute of Medical Sciences, Bhubaneswar, India

ORCID: 0000-0002-2131-5728

bandyasahoo@gmail.com

\section{Dr Reshmi Mishra}

MD (Pediatrics)

Associate Professor, Dept of Pediatrics,

Kalinga Institute of Medical Sciences, Bhubaneswar, India

docreshmis@gmail.com 
ORCID: 0000-0003-2504-9639

\author{
8. Dr Manas Ranjan Behera \\ MD (Pediatrics) \\ Professor in Pediatrics, \\ Kalinga Institute of Medical Sciences, Bhubaneswar, India \\ ORCID: 0000-0002-6099-6116 \\ drmanas73@yahoo.co.in
}

\title{
Correspondence to:
}

\author{
Dr Sibabratta Patnaik \\ Associate Professor, Paediatrics, \\ Kalinga Institute of Medical Sciences, Bhubaneswar, India \\ Mail: drsbpatnaik45@gmail.com
}

$+919437322267$

\section{$\underline{\text { Abstract }}$}

Background: Multi System Inflammatory Syndrome in children (MIS-C) associated with COVID-19 is a recently recognised potentially life-threatening entity. There is limited data on post MIS-C sequelae.

Methods: 21 children fulfilling the WHO criteria for MIS-C were included in our study. Data was collected at baseline and at 12-16 weeks post discharge to look for any persistent sequelae mainly relating to the lungs or heart including coronary arteries

Results: Fever was the most common presentation, found in $18(85.7 \%)$ patients. All had marked hyper-inflammatory state. Low ejection fraction (EF) was found in $10(47.6 \%)$, but none had any coronary artery abnormality. All received corticosteroids, while 7 (33.3\%) children required additional treatment with intravenous Immunoglobulins. 20 children improved while 1 left against medical advice. At discharge, 3 children had impaired left ventricular function. 
medRxiv preprint doi: https://doi.org/10.1101/2021.06.23.21259292; this version posted June 28, 2021. The copyright holder for this preprint (which was not certified by peer review) is the author/funder, who has granted medRxiv a license to display the preprint in perpetuity.

It is made available under a CC-BY-NC-ND 4.0 International license .

At median 15 weeks' follow-up, no persistent complications were found. EF had returned to normal and no coronary artery abnormalities were found during repeat echocardiography. Chest radiographs showed no fibrosis and all biochemical parameters had normalized.

Conclusion: The children with MIS-C are extremely sick during the acute stage. Timely and adequate management led to full recovery without any sequelae at a median follow-up of 15 weeks.

Keywords- follow-up, MIS-C, multi-inflammatory syndrome, outcomes, paediatric COVID19

Abbreviations: MIS-C: Multi System Inflammatory Syndrome in children, EF: Ejection fraction, KD: Kawasaki Disease, PAI-1: plasminogen activator inhibitor $\square$ 1, CRP: C-reactive protein, LDH: Lactate dehydrogenase, LMWH: Low molecular weight heparin

\section{Introduction:}

Multi-System Inflammatory Syndrome in children associated with COVID 19 (MIS-C) is a relatively new problem precipitated by the coronavirus pandemic. Since first time reported from England in April 2020[1], this disease has emerged as a problem for children and adolescents. It was shown to present with acute heart failure as a part of an hyperinflammatory response[2]. As the disease is relatively new, many new concepts are coming up in recent studies. MIS-C has a broad spectrum of presentation, some having mild symptoms while others have severe symptoms requiring intensive care support[3]. The disease usually presents 6 to 8 weeks after the viral infection and thought to be immune mediated. The hyper-inflammation in MIS-C differs from that of acute COVID-19 [4]. The 
medRxiv preprint doi: https://doi.org/10.1101/2021.06.23.21259292; this version posted June 28, 2021. The copyright holder for this preprint (which was not certified by peer review) is the author/funder, who has granted medRxiv a license to display the preprint in perpetuity.

It is made available under a CC-BY-NC-ND 4.0 International license .

MIS-C cases have many similarities with Kawasaki disease (KD), though MIS-C children are substantially older and have much severe inflammation. A quarter of patients have features of $\mathrm{KD}$, while another quarter of patients may have features of incomplete $\mathrm{KD}[5]$. Though the disease presents with profound inflammation, the mortality is around $1-2 \%[5,6]$.

However, there is little knowledge about the squeal or post-discharge complications of this set of patients. Like $\mathrm{KD}$, some may have pre-mature coronary artery disease with acute cardiac event. The SARS-CoV-2 virus activates the thrombosis cascade via several mechanisms and also induces the overexpression of plasminogen activator inhibitor $\square 1$ (PAI $\square$ 1) [7]. PAI-1 has also been found to be overexpressed in Kawasaki disease and is associated with development of coronary artery aneurysms [8]. Thus, patients with MIS-C may have a risk of developing coronary artery aneurysms on follow-up.

Similar illness can also be caused by other respiratory viruses or emerging new viral illnesses. Thus there is an urgent need to follow up a cohort of MIS-C patients to determine their short term and long term outcomes. We have examined the short term outcomes in our cohort of 21 children with MIS-C including detailed clinical and laboratory data.

\section{Methods:}

\section{Participants:}

A cohort of MIS-C was built at the department of Paediatrics of Kalinga Institute of Medical Sciences, Bhubaneswar over the last 1 year. All the children below 19 years fitting to WHO criteria[9] for MIS-C were included in the study. This included fever, rash, shock, heart failure, coagulopathy, gastrointestinal manifestations in the presence raised acute phase reactants, evidence of recent COVID-19 infection and exclusion of other causes of sepsis. For all patients RT-PCR testing of nasopharyngeal swab was carried out for SARS-CoV-2. Antibodies to SARS-COV-2 were detected using Elecsys ${ }^{\circledR}$ immunoassay kit [Roche 
medRxiv preprint doi: https://doi.org/10.1101/2021.06.23.21259292; this version posted June 28, 2021. The copyright holder for this preprint (which was not certified by peer review) is the author/funder, who has granted medRxiv a license to display the preprint in perpetuity.

It is made available under a CC-BY-NC-ND 4.0 International license .

diagnostics, Basel, Switzerland] as per the manufacturer's instructions. The assay uses recombinant protein representing the nucleocapsid antigen for detecting the antibody.

\section{Data collection:}

Data collected at admission, included age, gender, clinical profile, investigations including echocardiography and chest radiographs. During hospital stay, treatments provided and outcomes till discharge were recorded.

\section{Follow-up:}

After discharge, children were followed-up monthly for persistent clinical features or the emergence of any new symptoms. At 3 to 4 months after discharge, patients were routinely investigated for complete blood count, C-reactive protein (CRP), renal function, liver function, D-dimer, ferritin and lactate dehydrogenase (LDH). Chest radiographs and echocardiography was done for all patients.

\section{Statistics:}

Statistical analysis was carried out with SPSS software version 20. Normality of data were checked by the Shapiro Wilk test. Since the data were non-parametric, continuous variables were expressed as median, with inter-quartile range. Categorical variables were expressed as frequencies (percentages). Mann-Whitney $U$ was used to compare means of continuous variables while the Fisher Exact test was used to compare proportions of categorical variables. $\mathrm{P}$ value less than 0.05 was taken as statistically significant.

\section{Ethics:}

Ethical clearance had been obtained from the Institute Ethics Committee of the Kalinga Institute of Medical Sciences, Bhubaneswar (Reference no: KIIT/KIMS/IEC/542/2021) for this study. Written informed consent was taken from parents. 
medRxiv preprint doi: https://doi.org/10.1101/2021.06.23.21259292; this version posted June 28, 2021. The copyright holder for this preprint (which was not certified by peer review) is the author/funder, who has granted medRxiv a license to display the preprint in perpetuity.

It is made available under a CC-BY-NC-ND 4.0 International license .

\section{Result:}

There were a total 21 children enrolled in our cohort; 13(62\%) of them were male, with mean age of presentation was $8.48( \pm 4.3)$ years. Fever was the most common manifestation followed by rash. The children had features of involvement of the gastrointestinal system, the respiratory system and the cardiovascular system [Table 1].

Nine (43\%) children developed shock, requiring critical care with inotropic support, either at presentation or during hospital stay. Only one child had features of encephalitis. Twenty (95\%) children had high titre of COVID-19 antibody. Two children were positive by both RTPCR and antibody testing. Only a few of the parents (28.6\%) could remember contact with COVID-19 patients in past 6-8 weeks.

There was marked hyper-inflammatory state as evident by various acute phase reactants [Table II]. The majority of patients had normal leucocyte counts. Anaemia and hypoalbuminemia were common. On echocardiography,10 children had low ejection fraction. However, none of the children had coronary artery abnormality.

\section{Outcome at discharge:}

Out of 21 children, 1 child left against medical advice while 20 children continued treatment in our hospital. Ten $(50 \%)$ were managed in the paediatric intensive care unit with indications of either respiratory distress needing oxygen support, shock requiring inotropes or congestive cardiac failure. Five (25\%) children required non-invasive ventilation (NIV) support and only 1 child was intubated and ventilated. One child with mild symptoms was treated with oral steroid while rest 19 (95\%) children received intravenous methyl-prednisolone (MPS). Intravenous immunoglobulin (IVIG) was used along with intravenous MPS in 7 (35\%) patients. Post pulse MPS for 3 days, patients received tapering doses of oral steroids over the next 2-3 weeks. Low molecular weight heparin (LMWH) was introduced to all cases as per 
medRxiv preprint doi: https://doi.org/10.1101/2021.06.23.21259292; this version posted June 28, 2021. The copyright holder for this preprint (which was not certified by peer review) is the author/funder, who has granted medRxiv a license to display the preprint in perpetuity.

It is made available under a CC-BY-NC-ND 4.0 International license .

protocol. The average stay in the hospital was $8.6( \pm 3.2)$ days. At discharge; all were hemodynamically stable, while $3(15 \%)$ had mild left ventricular (LV) dysfunction.

\section{Follow-up at 3-4 months:}

Between 12 to 16 weeks after discharge, 16 children turned up for follow up. All children were hemodynamically stable without any major health problem. We repeated the blood counts and biochemistry. The hematologic and inflammatory parameters had normalised in all patients. (Table II) Follow up echocardiography of 15 children were normal, there were no evidence of coronary dilatation in any of our patients. One child who had global hypokinesia at admission, was found to have mild tricuspid regurgitation at 12 weeks' follow-up. Another girl had feature of astasia abasia. She presented with inability to walk properly though clinical examination revealed no abnormality. All relevant investigations including magnetic resonance imaging of the brain and electroencephalogram were normal. The symptoms subsided in 12 weeks with proper counselling and psychiatrist consultation.

\section{Discussion:}

Our follow-up of MIS-C patients was to determine any sequel or delayed manifestation of this newly-described syndrome. In our cohort, we did not find any such sequel including any development of coronary artery aneurysms.

At presentation, three patients did not have any history of fever. Though by definition, fever was an essential criterion, they matched all other criteria for MIS-C [9].They might have had mild to moderate fever at onset which was missed at home. Reviews of previous cases have also revealed fever in around $80 \%$ cases [10].

In a pooled meta-analysis of features of MIS-C, myocardial involvement was approximately found in $60 \%$ [11]. This is comparable with that of our cohort. Initial reports of COVID-19 
medRxiv preprint doi: https://doi.org/10.1101/2021.06.23.21259292; this version posted June 28, 2021. The copyright holder for this preprint (which was not certified by peer review) is the author/funder, who has granted medRxiv a license to display the preprint in perpetuity.

It is made available under a CC-BY-NC-ND 4.0 International license .

associated MIS-C cases describe ventricular dysfunction, coronary artery changes, atrioventricular valve regurgitation and pericardial effusions [2, 12, 13]. This warranted proper follow up of these cases to look for long term sequel. In our study we could show that none of these re-occurred in the follow-up period of 3-4 months.

We found neurologic involvement in four children, and one of them presented with features of encephalitis. A review that included 6 cohorts of MIS-C, found that $38 \%$ out of 187 children had some neurological issues [14]. Post-infectious immune mediated mechanism might be responsible for such issues, though more studies are required to substantiate it. Similar to myocardial involvement, there have been several reports of brain involvement in MIS-C and serial imaging of both the brain and the heart have been suggested [15].

Psychological issue in the form of astasia-abasia was found in one adolescent girl, few days after discharge from hospital. It was attributed to a somatoform disorder induced by ICU stay. She had improved over a period of 12 weeks.

Gastrointestinal involvement was common (76\%) in our cohort. There are case reports of MIS-C patients presenting with pain abdomen and diarrhoea, and then developing Kawasaki like features including mucositis, and coronary artery dilatation [16]. Some patients have been admitted with a suspicion of appendicitis [17].

Maculopapular rashes and conjunctival congestion can be considered as features overlapping with complete and incomplete Kawasaki disease; and has been reported in 30-70\% cases [11]. High d-dimer is found to be associated with poor outcome in many studies, but exact implication of high D-dimer is not yet understood [18].

As MIS-C is a hyper-inflammatory condition; immunomodulators play a major role in management. All of our patients had received corticosteroids. The decision to start IVIG in 7 patients was taken based on severity of the condition and also if the patient had not improved 
medRxiv preprint doi: https://doi.org/10.1101/2021.06.23.21259292; this version posted June 28, 2021. The copyright holder for this preprint (which was not certified by peer review) is the author/funder, who has granted medRxiv a license to display the preprint in perpetuity.

It is made available under a CC-BY-NC-ND 4.0 International license .

after the initial methyl prednisolone pulse. Combination of IVIG and methyl prednisolone is recommended for high risk cases including infants and in patients with coronary changes [19].

The American College of Rheumatology has recommended therapeutic anticoagulation in cases with ejection fraction $(\mathrm{EF})<35 \%$, documented thrombosis or coronary artery z-score more than 10 [19]. All of our patients had received LMWH. Severe disease is more common in 6-12year age group and the children with increased concentrations of CRP, ferritin, Ddimer and low platelets and lymphocytes were more likely to have shock or require ICU admission [20].

Supplemental oxygen was required in 10 patients; 5 required NIV support while a child with features of cardiogenic shock with pulmonary oedema required intubation and ventilation. A similar study from Mumbai in India had demonstrated high rate of invasive ventilation (39.1\%) [21]. In the previously mentioned systematic review, the need for invasive ventilation was around 25\%, while vasopressors were needed in more than 50\% [3].

All the children were asymptomatic and clinically stable during follow up between 12-16 weeks after discharge. Laboratory parameters were within normal limits. Three children had mild LV dysfunction at discharge that normalized on follow-up. One study on echocardiographic follow-up of MIS-C patients for 7 days has shown good recovery of cardiac function [22].

In a recent Indian study of 32 patients, ventricular dysfunction was found in 13 patients; 11 had normal ejection fraction at 2 weeks follow up while rest 2 were also normal by 6 weeks [16]. Persistent abnormalities in strain and diastolic function in patients with MIS-C with normal EF has also been reported [17]. This points to requirement of multicentre longitudinal follow up studies for MIS-C. 
medRxiv preprint doi: https://doi.org/10.1101/2021.06.23.21259292; this version posted June 28, 2021. The copyright holder for this preprint (which was not certified by peer review) is the author/funder, who has granted medRxiv a license to display the preprint in perpetuity.

It is made available under a CC-BY-NC-ND 4.0 International license .

Neurological manifestations improved before discharge in all, but one adolescent girl had somatoform disorder which persisted for more than 8 weeks. Amongst COVID-19 survivors, $17.4 \%$ had anxiety disorder, and $13.7 \%$ had mood disorder at 6-month follow-up [23]. Severe disease is associated with more chance of psychological issues.

There was no mortality reported in our cohort. In a systematic review, the mortality was described 18 (1.9\%) deaths out of 953 cases [5]. Most of these cases presented with shock, and many had comorbidities like G6PD deficiency, obesity, leukaemia, asthma and chronic neurologic disorders. In a multi-centric cohort of 76 cases of MIS-C, 75 (98.6\%) cases recovered without a significant sequel [24].

The limitation of our study include the small number of patients. However, MIS-C is a comparatively rare complication and to the best of our knowledge, limited cases of follow-up of such patients after discharge from hospital has been reported till now [24, 25].

\section{Conclusion:}

MIS-C is a new challenge in this COVID-19 pandemic era. A Broad case definition, lack of specific diagnostic tests and management guidelines, and uncertainty about long-term outcomes are major hurdles in its management. Our cohort showed that the morbidity of MIS-C was reversible with proper treatment and there was no significant complication or sequel at a median of 3.5-month follow-up. This study helps to dispel concerns of development of Kawasaki-like coronary artery aneurysms in MIS-C patients, if timely treatment is given. Longer studies with larger number of patients can confirm this.

\section{References:}

1. Riphagen S, Gomez X, Gonzalez-Martinez C, et al (2020) Hyperinflammatory shock in children during COVID-19 pandemic. Lancet 395:1607-1608.

https://doi.org/10.1016/S0140-6736(20)31094-1 
medRxiv preprint doi: https://doi.org/10.1101/2021.06.23.21259292; this version posted June 28, 2021. The copyright holder for this preprint (which was not certified by peer review) is the author/funder, who has granted medRxiv a license to display the preprint in perpetuity.

It is made available under a CC-BY-NC-ND 4.0 International license .

2. Belhadjer Z, Méot M, Bajolle F, et al (2020) Acute Heart Failure in Multisystem Inflammatory Syndrome in Children in the Context of Global SARS-CoV-2 Pandemic. Circulation 142:429-436. https://doi.org/10.1161/CIRCULATIONAHA.120.048360

3. Abrams JY, Godfred-Cato SE, Oster ME, et al (2020) Multisystem Inflammatory Syndrome in Children Associated with Severe Acute Respiratory Syndrome Coronavirus 2: A Systematic Review. J Pediatr 226:45-54.e1. https://doi.org/10.1016/j.jpeds.2020.08.003

4. Consiglio CR, Cotugno N, Sardh F, et al (2020) The Immunology of Multisystem Inflammatory Syndrome in Children with COVID-19. Cell 183:968-981.e7. https://doi.org/10.1016/j.cell.2020.09.016

5. Hoste L, Van Paemel R, Haerynck F (2021) Multisystem inflammatory syndrome in children related to COVID-19: a systematic review. Eur J Pediatr. https://doi.org/10.1007/s00431-021-03993-5

6. Dufort EM, Koumans EH, Chow EJ, et al (2020) Multisystem Inflammatory Syndrome in Children in New York State. New England Journal of Medicine 383:347-358. https://doi.org/10.1056/NEJMoa2021756

7. Ahmed S, Zimba O, Gasparyan AY (2020) Thrombosis in Coronavirus disease 2019 (COVID-19) through the prism of Virchow's triad. Clin Rheumatol 39:2529-2543. https://doi.org/10.1007/s10067-020-05275-1

8. Senzaki H, Kobayashi T, Nagasaka H, et al (2003) Plasminogen activator inhibitor-1 in patients with Kawasaki disease: diagnostic value for the prediction of coronary artery lesion and implication for a new mode of therapy. Pediatr Res 53:983-988. https://doi.org/10.1203/01.PDR.0000061566.63383.F4

9. Multisystem inflammatory syndrome in children and adolescents temporally related to COVID-19. https://www.who.int/news-room/commentaries/detail/multisysteminflammatory-syndrome-in-children-and-adolescents-with-covid-19. Accessed 23 May 2021

10. Bastug A, Aslaner H, Aybar Bilir Y, et al (2021) Multiple system inflammatory syndrome associated with SARS-CoV-2 infection in an adult and an adolescent. Rheumatol Int 41:993-1008. https://doi.org/10.1007/s00296-021-04843-1

11. Jiang L, Tang K, Levin M, et al (2020) COVID-19 and multisystem inflammatory syndrome in children and adolescents. Lancet Infect Dis 20:e276-e288. https://doi.org/10.1016/S1473-3099(20)30651-4

12. Verdoni L, Mazza A, Gervasoni A, et al (2020) An outbreak of severe Kawasaki-like disease at the Italian epicentre of the SARS-CoV-2 epidemic: an observational cohort study. Lancet 395:1771-1778. https://doi.org/10.1016/S0140-6736(20)31103-X

13. DeBiasi RL, Song X, Delaney M, et al (2020) Severe Coronavirus Disease-2019 in Children and Young Adults in the Washington, DC, Metropolitan Region. J Pediatr 223:199-203.e1. https://doi.org/10.1016/j.jpeds.2020.05.007 
medRxiv preprint doi: https://doi.org/10.1101/2021.06.23.21259292; this version posted June 28, 2021. The copyright holder for this preprint (which was not certified by peer review) is the author/funder, who has granted medRxiv a license to display the preprint in perpetuity.

It is made available under a CC-BY-NC-ND 4.0 International license .

14. Chen T-H (2020) Neurological involvement associated with COVID-19 infection in children. J Neurol Sci 418:117096. https://doi.org/10.1016/j.jns.2020.117096

15. Mavrogeni SI, Kitas GD, Dimitroulas T, et al (2016) Cardiovascular magnetic resonance in rheumatology: Current status and recommendations for use. International Journal of Cardiology 217:135-148. https://doi.org/10.1016/j.ijcard.2016.04.158

16. H K, Jy S, Jh K, et al (2020) Multisystem Inflammatory Syndrome in Children Related to COVID-19: the First Case in Korea. Journal of Korean medical science 35:. https://doi.org/10.3346/jkms.2020.35.e391

17. Lee JH, Han HS, Lee JK (2021) The Importance of Early Recognition, Timely Management, and the Role of Healthcare Providers in Multisystem Inflammatory Syndrome in Children. J Korean Med Sci 36:e17. https://doi.org/10.3346/jkms.2021.36.e17

18. Levi M, Thachil J, Iba T, Levy JH (2020) Coagulation abnormalities and thrombosis in patients with COVID-19. Lancet Haematol 7:e438-e440. https://doi.org/10.1016/S23523026(20)30145-9

19. Henderson LA, Canna SW, Friedman KG, et al (2021) American College of Rheumatology Clinical Guidance for Multisystem Inflammatory Syndrome in Children Associated With SARS-CoV-2 and Hyperinflammation in Pediatric COVID-19: Version 2. Arthritis Rheumatol 73:e13-e29. https://doi.org/10.1002/art.41616

20. Abrams JY, Oster ME, Godfred-Cato SE, et al (2021) Factors linked to severe outcomes in multisystem inflammatory syndrome in children (MIS-C) in the USA: a retrospective surveillance study. Lancet Child Adolesc Health 5:323-331.

https://doi.org/10.1016/S2352-4642(21)00050-X

21. Dhanalakshmi K, Venkataraman A, Balasubramanian S, et al (2020) Epidemiological and Clinical Profile of Pediatric Inflammatory Multisystem Syndrome - Temporally Associated with SARS-CoV-2 (PIMS-TS) in Indian Children. Indian Pediatr 57:10101014

22. Matsubara D, Kauffman HL, Wang Y, et al (2020) Echocardiographic Findings in Pediatric Multisystem Inflammatory Syndrome Associated With COVID-19 in the United States. J Am Coll Cardiol 76:1947-1961. https://doi.org/10.1016/j.jacc.2020.08.056

23. Taquet M, Geddes JR, Husain M, et al (2021) 6-month neurological and psychiatric outcomes in 236 $\square 379$ survivors of COVID-19: a retrospective cohort study using electronic health records. Lancet Psychiatry 8:416-427. https://doi.org/10.1016/S22150366(21)00084-5

24. Haslak F, Barut K, Durak C, et al (2021) Clinical features and outcomes of 76 patients with COVID-19-related multi-system inflammatory syndrome in children. Clin Rheumatol. https://doi.org/10.1007/s 10067-021-05780-x

25. Sugunan S, Bindusha S, Geetha S, et al (2021) Clinical Profile and Short-Term Outcome of Children with SARS-CoV-2 Related Multisystem Inflammatory Syndrome(MIS-C) Treated with Pulse Methylprednisolone. Indian Pediatr 
Table I: Demography and Clinical Characteristics

\begin{tabular}{|c|c|}
\hline Demography & \\
\hline Total Patients & 21 \\
\hline Male: Female & 1.6 \\
\hline Age in years, Median IQR & $8.5,(2-16)$ \\
\hline Left against medical advice & 1 \\
\hline Symptoms & $\mathbf{N}(\%)$ \\
\hline Fever & $18(85.7)$ \\
\hline Rashes & $17(81)$ \\
\hline Conjunctivitis & $12(57)$ \\
\hline Gastrointestinal System & $16(76)$ \\
\hline Loose motion & 16 \\
\hline Vomiting & 8 \\
\hline Pain abdomen & 10 \\
\hline Respiratory System & $12(57)$ \\
\hline Cough & 5 \\
\hline Respiratory distress & 12 \\
\hline Crepitation & 6 \\
\hline Cardiovascular System & $12(57)$ \\
\hline Shock & $9(43)$ \\
\hline Gallop & 4 \\
\hline Congestive heart failure & 5 \\
\hline ECHO changes (Low EF) & 10 \\
\hline Neurologic symptoms & 5 \\
\hline \multicolumn{2}{|l|}{ Treatment $(\mathrm{n}=20)$} \\
\hline IVIG & $7(33 \%)$ \\
\hline Steroids & $20(100 \%)$ \\
\hline LMWH & $20(100 \%)$ \\
\hline ICU requirement & $10(50 \%)$ \\
\hline Mechanical ventilation (NIV and intubation) & $5(25 \%)$ \\
\hline Inotropes & $9(45 \%)$ \\
\hline
\end{tabular}




\section{Table II: Laboratory Profile of children with MIS-C}

\begin{tabular}{|l|l|l|}
\hline Parameters & $\begin{array}{l}\text { At admission } \\
\text { Median (IQR) }\end{array}$ & $\begin{array}{l}\text { Follow up at 12 weeks } \\
\text { Median (IQR) }\end{array}$ \\
\hline Haemoglobin $(\mathrm{g} / \mathrm{dL})$ & $10.1(8.9-11.5)$ & $12.16(10.0-14.8)$ \\
\hline $\begin{array}{l}\text { Total leucocyte count } \\
\left(\text { per } \mathrm{mm}^{3}\right)\end{array}$ & $9,800(7,505-16,580)$ & $8,470(5100-12750)$ \\
\hline $\begin{array}{l}\text { Neutrophil count } \\
(\% \text { of TLC) }\end{array}$ & $67(55-81)$ & $48(30-74)$ \\
\hline $\begin{array}{l}\text { Lymphocyte count } \\
(\% \text { of TLC) }\end{array}$ & $26(21-34)$ & $44(20-61)$ \\
\hline $\begin{array}{l}\text { Platelet count }\left(\mathrm{X} 10^{5}\right. \\
\left.\mathrm{mm}^{3}\right)\end{array}$ & $1.8(1.2-3.0)$ & $2.71(1.1-4.6)$ \\
\hline \begin{tabular}{l} 
CRP $(\mathrm{mg} / \mathrm{L})$ \\
\hline Serum Ferritin $(\mathrm{ng} / \mathrm{mL})$
\end{tabular} & $364(249-720)$ & $36.2(11.9-61.5)$ \\
\hline d-Dimer $(\mu \mathrm{g} / \mathrm{mL})$ & $3.11(2.2-8.1)$ & $0.48(0.03-1.2)$ \\
\hline $\begin{array}{l}\text { Serum LDH (U/L) } \\
\text { CPK MB (IU/L) }\end{array}$ & $352(315-633)$ & $224.6(170-279)$ \\
\hline $\begin{array}{l}\text { Serum Creatinine } \\
(\mathrm{mg} / \mathrm{dL})\end{array}$ & $0.35(0.3-0.55)$ & $0.3(0.27-0.43)$ \\
\hline
\end{tabular}

